\title{
Castrul legionar de la Potaissa (Turda). 45 de ani De CERCETĂRI ARHEOLOGICE
}

MIHAI BĂRBULESCU

\section{REZUMAT:}

Studiul de sinteză înfățișează situația cercetării arheologice în castrul legiunii V Macedonica de la Potaissa (astăzi Turda, România) desfăşurată sistematic începând cu anul 1971. Castrul legiunii V Macedonica a funcționat din jurul anului 170 până la abandonarea Daciei. Au fost cercetate elementele de fortificare, porta decumana, bastioane de colț și de curtină, drumurile principale. Au fost cercetate exhaustiv principia și băile legiunii, iar parțial cazărmile cohortei milliaria, ale unor cohortes quingenariae și un complex de horrea. Castrul de la Potaissa se înscrie foarte bine în seria castrelor legionare construite ori refăcute sub Marcus Aurelius.

O variantă a acestui text a apărut în limba engleză în volumul Visy 75. Artificem commendat opus. Studia in honorem Zsolt Visy (eds. G. I. Farkas, Réka Neményi, M. Szabó), Pécs, 2019, p. 52-69.

\section{Abstract: The legionary fortress at Potaissa (Turda). 45 Years of archaeological RESEARCH}

This summary report offers an overall incursion into the state of research, as well as the systematic archaeological investigations undergone throughout the years at the legionary fortress of Legio V Macedonica from Potaissa (nowdays Turda, Romania), starting with the year 1971. The legionary fortress had functioned between approximately AD 170 and until the Roman withdrawal. Investigations have focused on the main defense elements, the western gate (porta decumana), the corner bastions, as well as the main roads of the fortress. The headquarters (principia) and the Roman baths have been fully researched, while the barracks of cohors I miliaria, some of the cohortes quingenariae, as well as the horrea complex have been partially investigated. All the results lead to the conclusion that the legionary fortress at Potaissa can be attributed to the series of fortresses built or rebuilt under the emperor Marcus Aurelius.

A variant of this paper appeared in English in the volume Visy 75. Artificem commendat opus. Studia in honorem Zsolt Visy (eds. G. I. Farkas, Réka Neményi, M. Szabó), Pécs, 2019, p. 52-69.

CuvinTE CHEIE: Potaissa, legiunea V Macedonica, castru legionar, principia, terme.

KEYWORDS: Potaissa, legio $5^{\text {th }}$ Macedonica, legionary fortress, principia, Roman baths.

Castrul legiunii a V-a Macedonica de la Potaissa a funcționat din jurul anului 170 până la retragerea armatei romane din Dacia, în vremea lui Gallienus ori sub Aurelian. Deși urmele castrului au fost totdeauna vizibile la suprafața terenului, cercetarea arheologică a debutat târziu, abia în 1958, cu un sondaj la bastionul sud-estic al fortificației ${ }^{1}$. Din 1971 cercetările în castru s-au desfășurat fără întrerupere până în $2016^{2}$, cărora li s-a adăugat un sondaj în 2019. În acest interval s-au executat cercetări arheologice și în oraşul Potaissa³

\footnotetext{
Crișan 1961, 431-439.

2 Prezentări generale ale castrului: Bărbulescu 1991, 22-30; Bărbulescu 1994, 195-214; Bărbulescu 1997; Bishop 2012, 109-110.

3 Bărbulescu 1994 a.
} 
Castrul este situat pe un platou (cota absolută $371 \mathrm{~m}$ ), mai ridicat cu vreo 30 m față de zona centrală a orașului antic, situată la sud-est de castru (Fig. 1-2). Castrul are forma unui dreptunghi orientat cu laturile lungi pe direcția NV - SE (fig. 3). Cele mai recente măsurători ale castrului, din toamna anului 2019, după ce s-a putut preciza mai corect poziția incintei estice (prin cercetările colegului Dan Matei), au dat suprafaţa interioară (fără grosimea zidurilor de incintă) de 580 x 408 m, adică 23,66 ha (considerând că forma castrului ar fi un dreptunghi perfect). Vechile măsurători erau 573 x 408 m, adică 23,37 ha4 .

Castrul se înscrie perfect în seria de castre construite în perioada războaielor marcomanice de Legiunea II Italica și Legiunea V Macedonica. Legiunea II Italica fusese înființată de Marcus Aurelius în anul 165. În anii următori legiunea își construiește primul castru, la Ločica, lângă Celeia (Pannonia Superior). După 168 Legiunea V Macedonica este adusă de la Troesmis (Moesia Inferior) la Potaissa. Pe la 173 Legiunea II Italica e mutată la Albing (Noricum). În ultimul deceniu al secolului al II-lea Legiunea II Italica construiește castrul de la Lauriacum (Noricum), de data aceasta forma nemaifiind rectangulară, iar suprafața ceva mai mică $(21,45 \text { ha })^{5}$.

Cele trei castre (Ločica, Potaissa, Albing) au, practic, aceeași suprafaţă:

$$
\begin{array}{lll}
\text { Ločica } & 543 \times 435,5 \mathrm{~m} & (23,64 \mathrm{ha}) \\
\text { Potaissa } & 580 \times 408 \mathrm{~m} & (23,66 \mathrm{ha}) \\
\text { Albing } & 568 \times 412 \mathrm{~m} & (23,40 \mathrm{ha})
\end{array}
$$

Mai mult, la Potaissa și Albing chiar și lungimea laturilor este foarte asemănătoare. Este evident că s-a aplicat un plan standardizat, elaborat în birourile centrale ale armatei romane, respectat în anii 166-173. De altfel, la

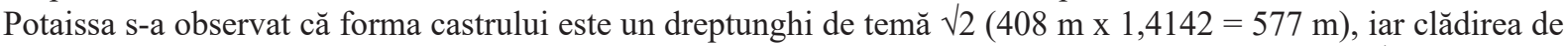
comandament (principia) are forma unui dreptunghi (124,60 - $125 \mathrm{~m} \mathrm{x} \mathrm{71,80} \mathrm{-} \mathrm{72,60} \mathrm{m)} \mathrm{de} \mathrm{temă} \sqrt{3}(72,20 \mathrm{~m} \mathrm{x}$ $1,732=125 \mathrm{~m}$ ). Punctul gromei (care nu poate fi stabilit cu exactitate, dar îl considerăm la intrarea în principia) marchează pe axul lung al castrului secțiunea de aur $(364 \mathrm{~m}: 216 \mathrm{~m}=1,685)$, în condițiile în care numărul de aur $\varphi=1,618^{6}$.

Incinta, porți și turnuri ${ }^{7}$. Din incinta castrului de la Potaissa se păstrează doar temelia, groasă de 1,70 - 2 m, construită în tehnica opus incertum. Elevația zidului de incintă era construită - cel puțin paramentul exterior - din blocuri fasonate (opus quadratum), din care câteva s-au găsit căzute spre exteriorul zidului. Complet cercetat a fost bastionul din colțul nord-vestic, cu formă ușor trapezoidală, racordând laturile castrului printr-o curbură cu raza de $18 \mathrm{~m}$. Laturile de est și vest ale bastionului erau lungi de 5,30-5,50 m, iar latura dinspre interiorul castrului era lungă de 11,40 m. Suprafața interioară a bastionului este de $33 \mathrm{~m}^{2}$. S-a constatat o refacere a bastionului, prin îngroșarea zidurilor. Un singur șanț înconjoară fortificația, larg de $12 \mathrm{~m}$, săpat în forma literei V, cu adâncimea maximă de 2,75 - $3 \mathrm{~m}$. Porțile praetoria și decumana se află la mijlocul laturii de est, respectiv vest, a castrului. Porțile principales împart laturile lungi ale castrului în raportul de aur $\varphi$ menționat mai sus. A fost complet cercetată porta decumana flancată de două turnuri rectangulare (8,95 x 6,25-6,80 m turnul nordic, 9,10 x 6,25 m turnul sudic, dimensiuni prin exterior). Cele două turnuri înaintează spre vest faţă de linia incintei cu 3,25 m. Spre spațiul porții turnurile au câte două contraforturi. În interiorul turnurilor există două nivele de călcare. Deschiderea porții, între turnuri este de 12,50 m. Porta decumana de la Ločica are deschiderea de 13,20 m . În centrul porții se află un zid median (spina), lung de 6,30 m și gros de 2,95 m, care împărțea poarta în două culoare, aproape egale. Prin jumătatea nordică trecea drumul de acces în castru, lat de 4,90 m. Culoarul nordic pare să fi fost barat de un zid, ulterior a fost redeschis și drumul refăcut. Este posibil ca închiderea porții să fi survenit în vremea războaielor carpice ale lui Filip Arabul, redeschiderea având loc sub Decius (?). La Brigetio, castru reconstruit sub Marcus Aurelius, porta decumana și porțile principales erau împărțite prin spina $a^{9}$, iar turnurile porții praetoria sunt foarte asemănătoare cu turnurile de la Potaissa ${ }^{10}$. Un singur turn de curtină a fost cercetat pe latura vestică, situat la jumătatea distanței dintre porta decumana și colțul nord-vestic al castrului. Avea dimensiunile 6,90 x 6-6,25 m (prin exterior). Nu știm câte turnuri de curtină existau. Este probabil ca pe laturile scurte să fi fost câte șase turnuri, ca la Ločica și Albing ${ }^{11}$.

4 Bărbulescu 1987, 98.

5 Winkler 1971, 85-107; Kandler, Vetters 1986, 92-109; Ployer 2013, 34-37; Groh 2018, 59.

6 Potrivit măsurătorilor anterioare (354 m : 219 m = 1,616), secțiunea de aur era aproape perfectă. Bărbulescu 1987, 173-188; Bărbulescu 2004, 17-31.

7 Bărbulescu 1987, 106-118.

8 Kandler 1979, 190.

9 Számadó, Borhy 2003, 77.

10 Bechert 1971, 249.

11 Kandler, Vetters 1986, 107. 


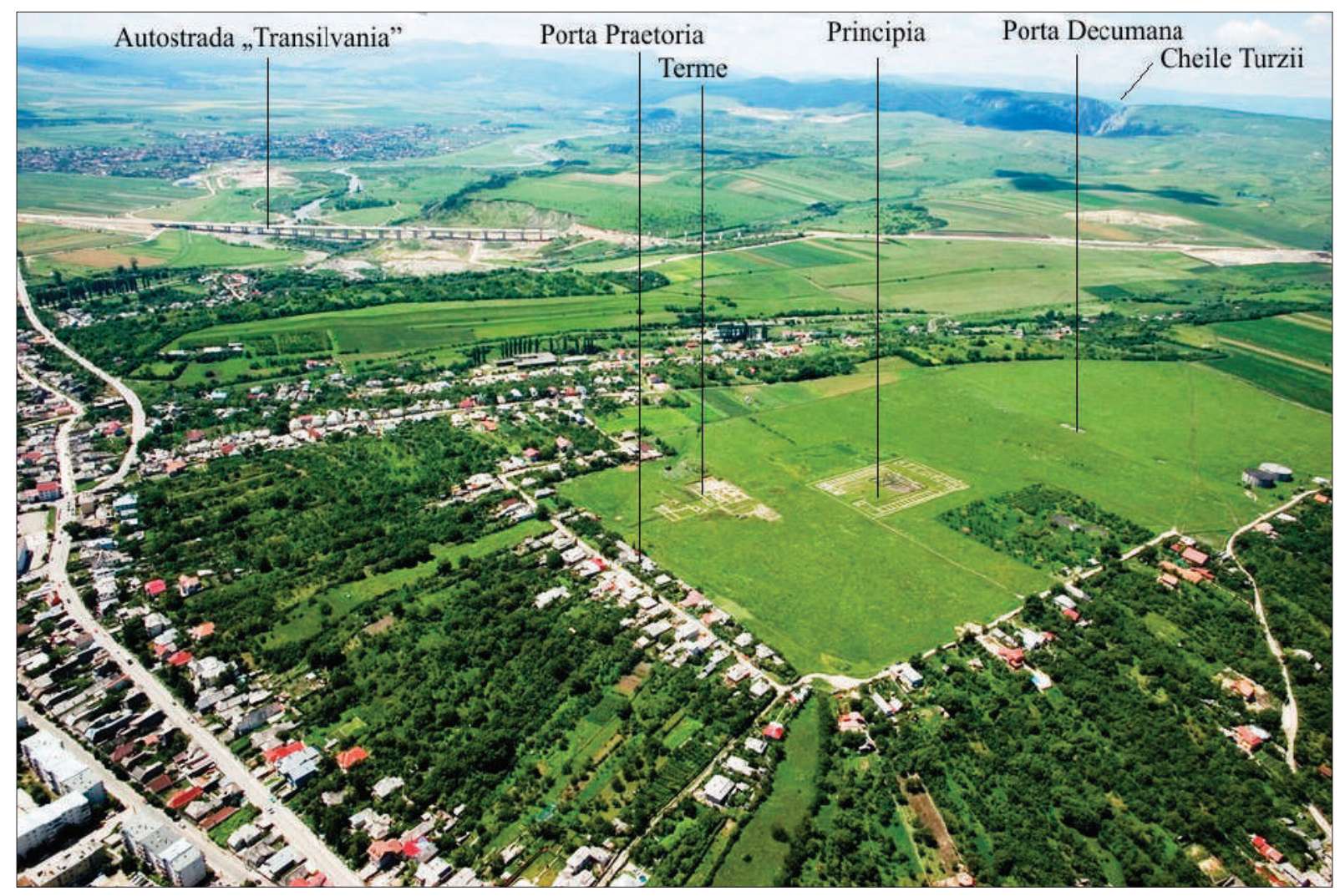

Figura 1. Castrul legionar de la Potaissa. Vedere generală (după Bărbulescu et al. 2019).
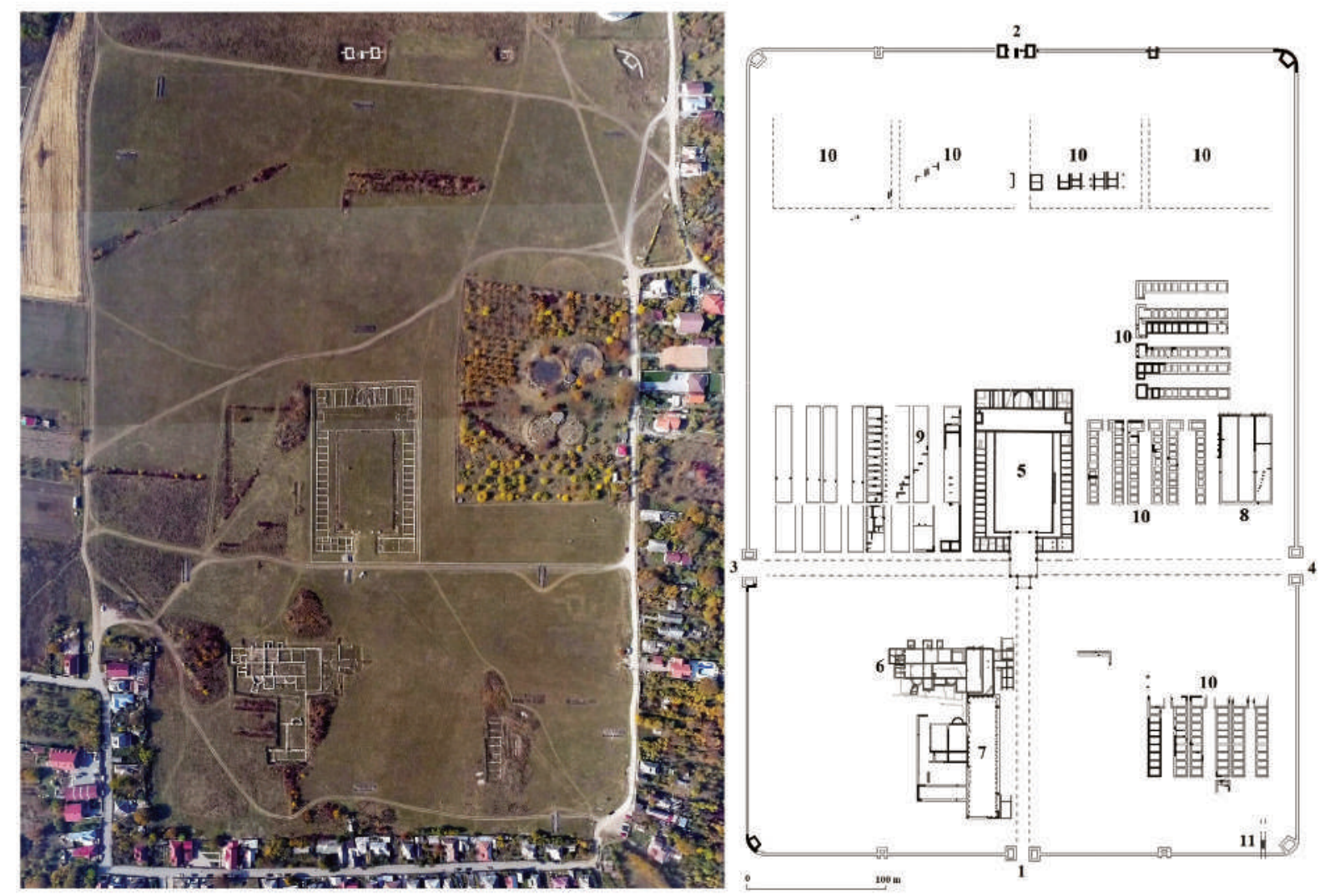

Figura 2. Castrul legionar de la Potaissa. Fotografie (Toma Bărbulescu) și plan. 


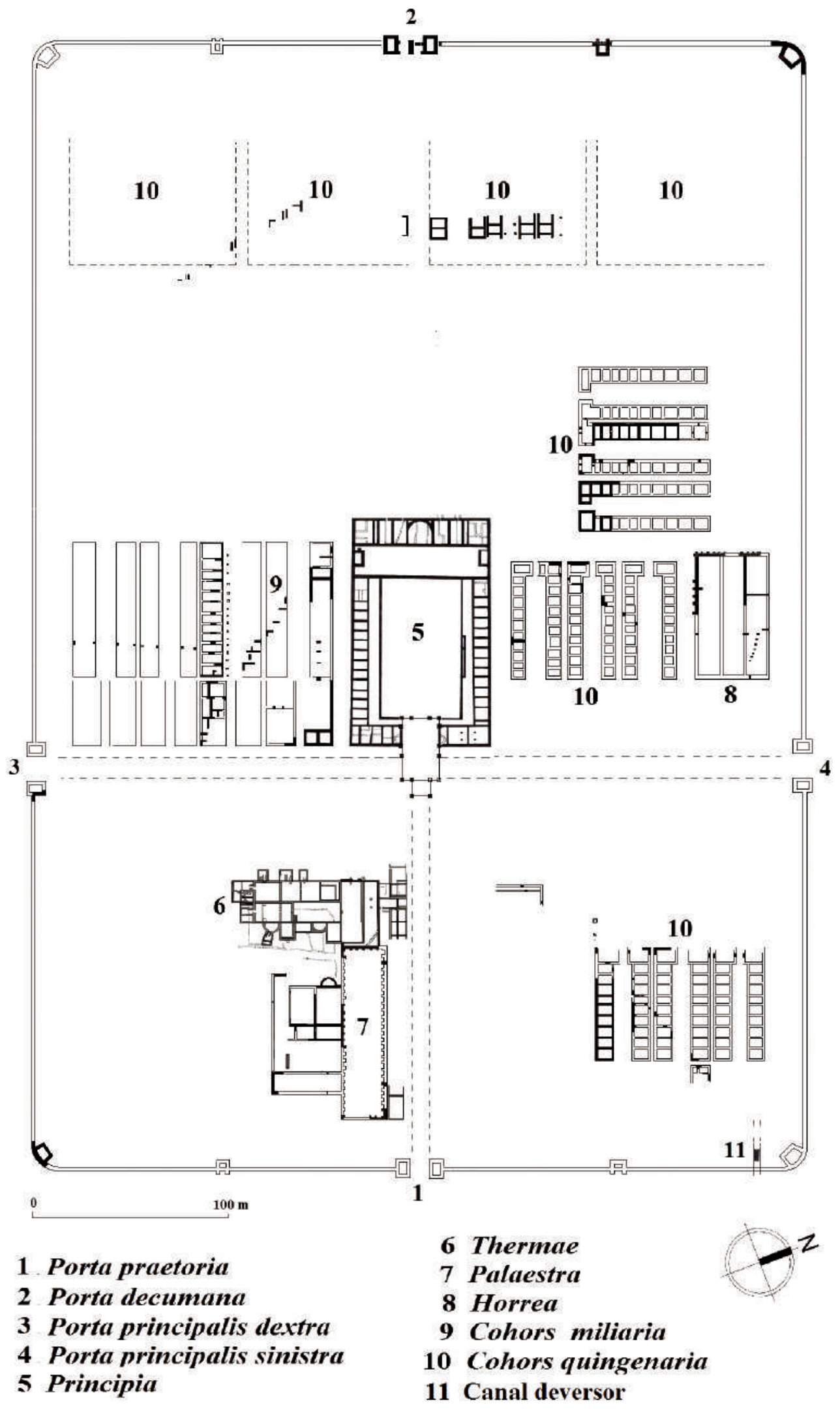

Figura 3. Castrul legionar de la Potaissa. Plan (2019). 
Drumuri $^{12}$. Via principalis este lată de $7-10 \mathrm{~m}$. Via praetoria este lată de 5,5-9,30 m. Drumurile sunt construite din marnă argiloasă, piatră de râu și pietriș. Nu s-au păstrat decât foarte puține lespezi din stratul superior, iar rigolele se observă cu greutate. Spre drumurile principale edificiile adiacente aveau portice, adânci de $4 \mathrm{~m}$ (porticul de la principia spre via principalis ori porticul intrării în terme spre via praetoria). Legătura cu drumul imperial principal și cu drumurile care străbăteau orașul se făcea mai lesnicios prin porta decumana, respectiv prin porta principalis dextra. În castru era și o rețea de drumuri secundare. De exemplu, clădirea comandamentului este flancată pe laturile de nord, vest și sud de viae vicinariae late de 3,5-6 m.

Principia $^{13}$ au fost cercetate integral ${ }^{14}$. Edificiul comandamentului se află în poziţia firească, cu frontul la via principalis, centrat pe axul lung al castrului (Fig. 4-5). Edificiul se înscrie într-un dreptunghi, cu laturile de nord și sud (inclusiv porticul exterior estic) lungi de 124,60 - $125 \mathrm{~m}$; lăţimea edificiului este de 71,80 m la latura vestică şi de 72,60 m la latura estică. Suprafața edificiului este de 0,899 ha, ceea ce înseamnă 3,8 \% din suprafața castrului. Ca mărime, principia de la Potaissa sunt similare cu cele de la Lambaesis $(0,88$ ha) şi Bonna $(0,83$ ha), construite în prima jumătate a secolului al II-lea, respectiv după anul $71^{15}$. Numai la Vetera I (castru pentru două legiuni) suprafața comandamentului $\left(1,13\right.$ ha) este mai mare decât la Potaissa ${ }^{16}$. Nicăieri în castrele legionare principia nu ocupă un procent atît de mare din suprafața castrului ca la Potaissa.

Principia la Potaissa aparțin tipului cu curte și sală acoperită (basilica) dispusă transversal pe curte (Querhalle, Cross Hall) ${ }^{17}$ (Fig. 6-7). Latura estică avea un portic spre via principalis.

Intrarea în principia se făcea prin groma, cu dimensiuni și plan stabilite prin sondajul din 2019. Edificiul groma (quadrifrons, tetrapylon) era situat peste încrucișarea dintre via principalis și via praetoria, ca la Lambaesis (epoca lui Hadrian), Albing, Lauriacum (a doua jumătate a secolului II), Aquincum (sfârșitul secolului II - începutul secolului III), Dura-Europos (anii 211-212), Palmyra (epoca lui Diocletian), el-Lejjūn (sec. IV) ${ }^{18}$, poate și Novae ${ }^{19}$. Recent pare să se fi atestat un mic tetrapylon în castrul auxiliar de la Romita ${ }^{20}$. Dacă adăugăm construcțiile (,Vorhalle”) care acoperă via principalis în dreptul clădirilor de comandament în castrele auxiliare din Germania și Raetia, mai rar în Britannia $^{21}$, ori porțile monumentale la intrarea în principia din castrele legionare de la Noviomagus și Novaesium ${ }^{22}$, putem concluziona că este foarte probabil ca la toate castrele să fi existat fie groma, fie acoperirea numai peste via principalis în dreptul clădirii de comandament, fie o tratare monumentală doar a intrării în principia. Necunoașterea lor este o carență a cercetării arheologice.

Groma de la Potaissa era un edificiu dreptunghiular, lung de aproximativ 35 m, larg de 17,80 m (60 pedes) între fundațiile pilonilor și 18,90 m între ziduri. Groma acoperea încrucișarea dintre via praetoria și via principalis, deschiderea din latura estică a clădirii comandamentului și porticele interioare și exterioare ale acesteia. Planul dreptunghiular al gromei se completa spre est cu un spațiu avansat (rezalit, ,ressaut”), dreptunghiular, care forma un ,porche” (,Vorhalle”) peste via praetoria. Împreună cu acest spațiu groma avea lungimea de aproximativ 40 m (între fundațiile pilonilor exteriori). Spre răsărit se găsea poarta pentru via praetoria, largă de cca 8 m (între fundațiile pilonilor) și intrările secundare retrase în plan. Spre vest, la intrarea în curte, se plasa poarta centrală, largă de 7,60 m (la Lambaesis intrarea centrală era largă de 7,08 m²3) și cele două intrări laterale, largi de câte 3 3,30 m. Laturile lungi ale gromei erau străpunse de porțile pentru via principalis, largi de cca 8,50 m, și de câte trei perechi de porți secundare pentru portice.

Groma diviza latura estică în două aripi. Aripa sudică este formată din încăperile I, J, K, L și M. În primele patru s-a introdus - probabil spre mijlocul secolului al III-lea, când s-au făcut și mici modificări planimetrice - sistemul de încălzire cu hipocaust. În aceste încăperi s-a descoperit o mare cantitate de ceramică, iar în spaţiul I exista și o fântână. Este posibil ca în această fază mai târzie a funcționării castrului aici să fi existat o schola, cu bucătărie

\footnotetext{
12 Bărbulescu 1987, 118-120.

13 Bărbulescu 1987, 122-164; Bărbulescu 1990, 821-831; Bărbulescu, Bărbulescu 2004, 27-33; Bărbulescu 2004, 32-57.

14 Un volum monografic despre principia se află în faza finală de elaborare de către colectivul de cercetare.

15 Petrikovits $1975,155,160$.

16 Fellmann 1983, 26

17 Fellmann 1958, 163-167.

18 Fellmann 1958, 171-173; Rakob, Storz 1974, 266; Szirmai 1976, 91-93; Fellmann 1983, 20, 74-75; Gawlikowski 1984, $65-$ 66; Kandler, Vetters 1986, 98; Póczy et al. 1986, 398; Lain, Parker 2006, 157; Groh 2018, 59.

19 Sarnowski 1995, 37-40.

20 Franzen et al. 2004-2005, 165; Cupcea et al. 2018, 19.

21 Johnson 1987, 140-146.

${ }^{22}$ Fellmann 1983, 20, 48; http://www.castrum-novaesium.de/EPrincipia.html.

23 Rakob, Storz 1974, fig. 9 și pl. 135, 2.
} 


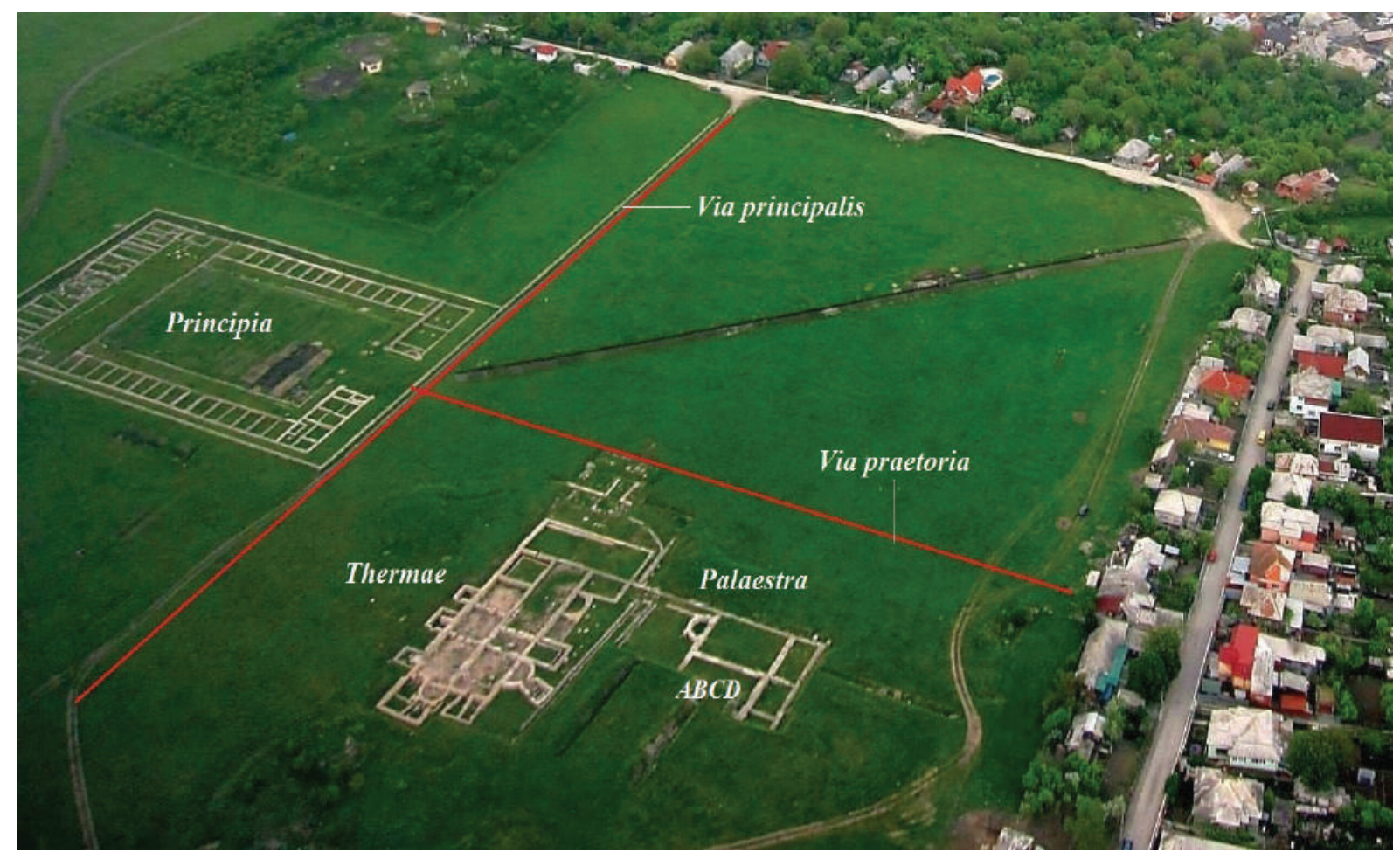

Figura 4. Principia și terme (după Bărbulescu et al. 2019).

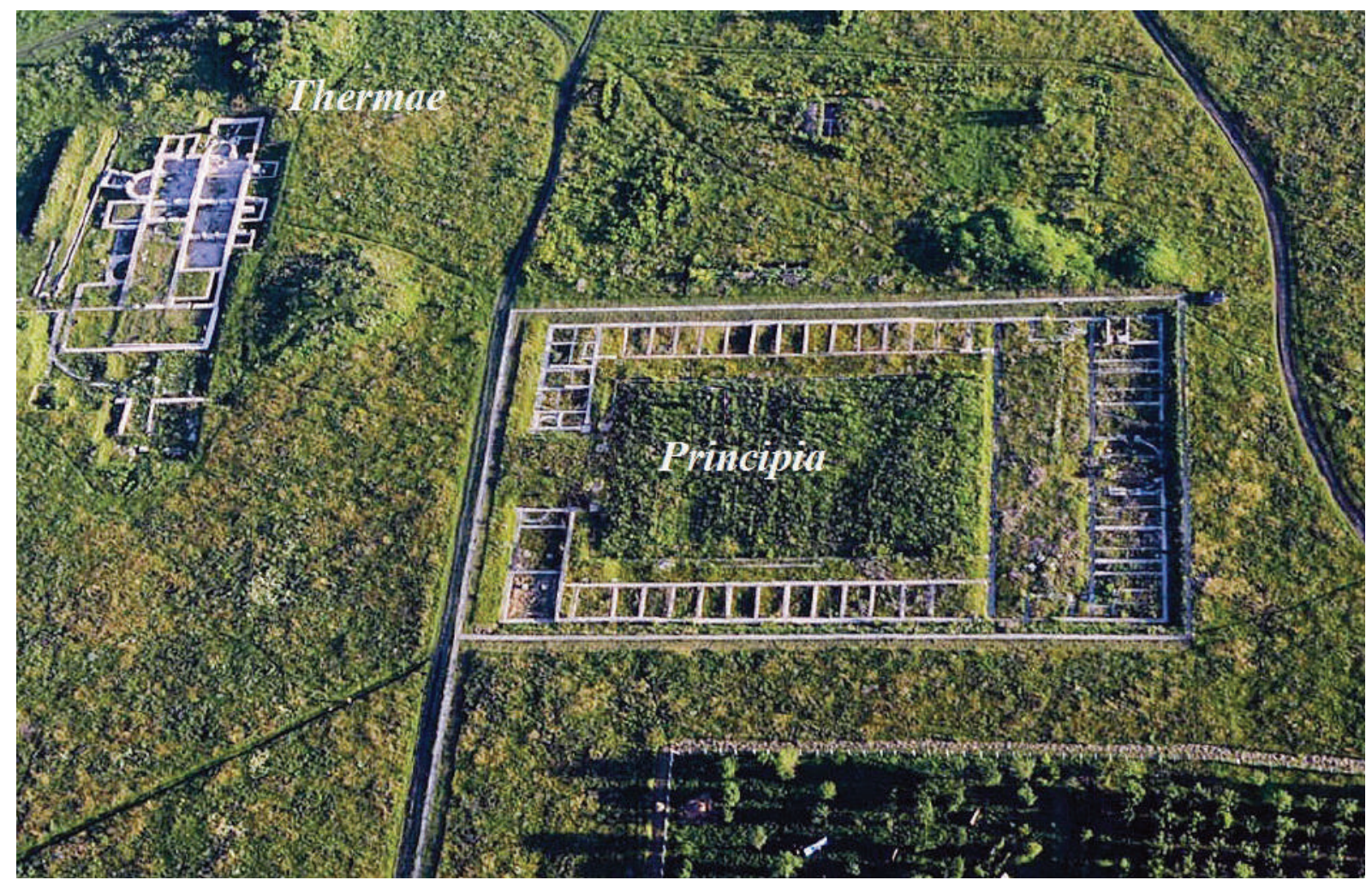

Figura 5. Principia și terme (după Bărbulescu et al. 2019). 
și loc de luat masa pentru personalul care lucra în principia, aşa cum s-a întâmplat și în principia de la Novae ${ }^{24}$. În spațiile M (aripa sudică) și N (aripa nordică) s-au descoperit câte o absidă, adică fundațiile pentru două nișe boltite care se deschideau spre groma. Ulterior s-a renunțat la cele două nișe, fundațiile absidate fiind demantelate și acoperite. În aripa nordică o modificare a survenit prin desființarea peretelui dintre spațiile $\mathrm{O}$ şi $\mathrm{P}$, creîndu-se o mare sală, de $200 \mathrm{~m}^{2}$, care a servit ca depozit. Aici s-au descoperit fragmente din aproape 500 de amfore, aproape toate pentru ulei. Aproape 90 \% din amfore aparțin tipului Dressel 24/Similis.

Laturile lungi ale clădirii comandamentului sunt formate din câte o amfiladă de încăperi (nr. 1-14 pe latura nordică, nr. 15-28 pe latura sudică, Fig. 7). Încăperea 14, cea mai mare din latura nordică, pare să fi fost încălzită într-o primă fază, funcționând ca schola (dovedită inclusiv prin fragmentele epigrafice descoperite aici). În latura sudică cea mai mare încăpere era 15, cu sistem de încălzire introdus mai târziu (poate deodată cu renunţarea la încălzire din spațiul 14). Restul încăperilor din laturile lungi erau neîncălzite. Camerele 3-13 și 16-28 aveau mărimea, prin interior, de 7,10 - 7,40 m x 4,40 - 4,90 m. Ele erau armamentaria, nu doar prin materialul arheologic descoperit, ci şi prin confirmare epigrafică: în încăperea $15 \mathrm{~s}$-a descoperit un altar dedicat Genio armamentarii de către un custos armorum $^{25}$. Până acum, un genius armamentarii era atestat doar la Novae, pe un altar dedicat de un custos armorum din legiunea I Italica. Altarul fusese descoperit în poziţie secundară, reutilizat într-o construcție târzie ${ }^{26}$, astfel încât nu contribuia la lămurirea poziției depozitului de armament într-un castru. Localizarea depozitului în principia părea a fi contrazisă de inscripția de la Lanchester, care făcea distincție între principia și armamentaria ${ }^{27}$. Descoperirea din castrul potaissens lămurește chestiunea: depozitul de armament se găsea în principia, în laturile lungi ale clădirii. Încăperea încălzită 15 era probabil biroul subofițerilor custodes armorum.

Laturile de răsărit, nord și sud ale edificiului de comandament aveau spre curte portice adânci de 3,60 - 4 m (la latura răsăriteană) și 5,30 - 5,40 m (la laturile de nord și sud). Acestea permiteau circulația în toate încăperile, în curte și în basilica. Cele două culoare D și D' din latura vestică a edificiului sunt plasate în dreptul porticelor de nord și sud, prin urmare se putea străbate principia în lungime numai prin spații acoperite (fig. 7). Porticele de nord și sud sunt lungi de 73 m. După dimensiunile fusurilor de coloană descoperite, coloanele porticelor, cu bază și capitel, aveau o înălțime de 2,60 - 2,80 m.

Curtea (forum) măsoară (fără portice) 41,50 x 73 m, ocupând o suprafaţă de 3029 m². Cu această suprafață pare a fi cea mai mare curte cunoscută în clădirile de comandament din castrele legionare, depășind-o chiar și pe cea de la Vetera I $\left(2805 \mathrm{~m}^{2}\right)$. Suprafața mare a edificiului de comandament la Potaissa este determinată tocmai de această suprafață neobișnuit de mare a curții. Dimensiunea de 140 pedes $(41,40 \mathrm{~m})$ se regăsește în curțile de la Potaissa (41,50 m), Carnuntum (curtea de 41,85 x 37,85 m) ${ }^{28}$, Lauriacum (curtea de 42 x 48 m) ${ }^{29}$ etc. În curte s-au descoperit puține lespezi de piatră din pavaj. În colțul sud-estic exista o fântână. S-au găsit fragmente de inscripții onorifice imperiale și fragmente din statui imperiale de bronz aurit.

Spre vest curtea se închide cu o basilica. Lungimea ei (prin interior 69,60 m) este egală cu lăţimea întregului edificiu, iar lățimea basilicii este de 16,65 - 16,90 m. În basilica se pătrundea din curte prin mai multe porți. Din elementele arhitectonice descoperite s-a putut face reconstituirea porţii centrale, largă de $6,12 \mathrm{~m}^{30}$. Din observațiile stratigrafice rezultă existența unor intrări în basilica și din porticele curții, corespunzând cu culoarele D și D' din latura vestică a edificiului. Asemenea intrări laterale în basilica, spre care duc porticele din curte, se cunosc la Dura-Europos, Chesters, Lambaesis ${ }^{31}$ etc. De la ferestrele basilicii provin fragmente de sticlă de geam.

În basilica nu s-au descoperit fundații pentru coloane ori stâlpi. Prin urmare, basilica erau uninavată. Se cunosc în castre basilici cu trei nave, ca la Lambaesis $(52 \text { x } 28 \text { m, din care nava centrală are 14,33 m) })^{32}$, sau la Isca (basilica de $64,40 \times 25$ m) $)^{33}$, ori numai cu două nave inegale, ca la Housesteads ${ }^{34}$. În pofida deschiderii foarte mari, basilica de la Potaissa a fost acoperită fără sprijinul intermediar al unor coloane ori stâlpi. Lățimea sa este cu puțin inferioară celor 60 pedes $(17,74 \mathrm{~m})$ acoperite fără sprijin intermediar, „recordul” stabilit de Vitruvius când a construit nava centrală a basilicii din Fanum ${ }^{35}$.

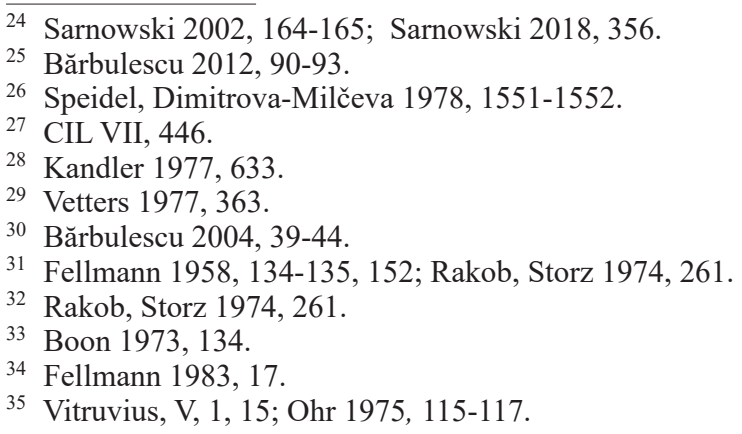



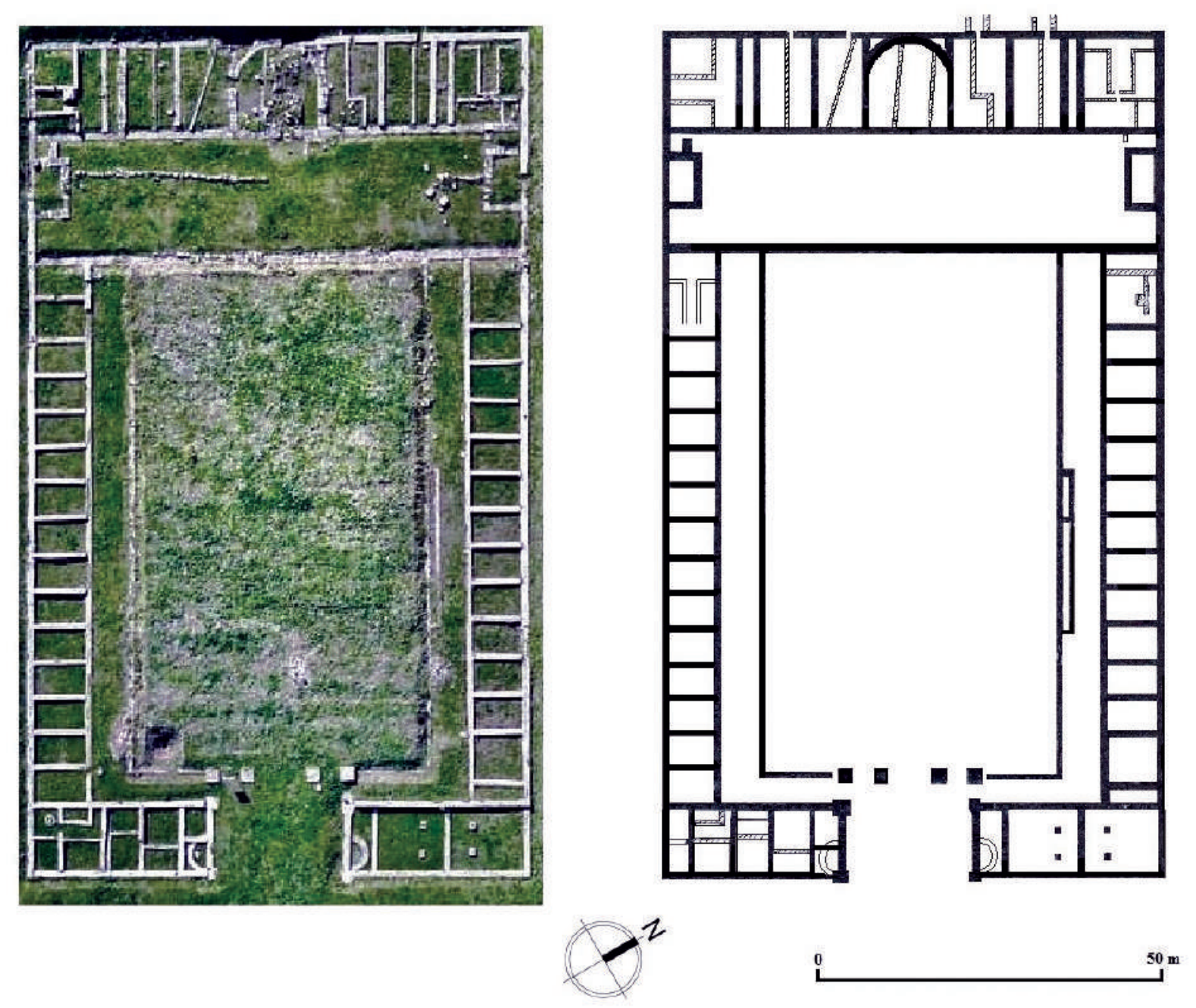

Figura 6. Principia Fotografie și plan. 


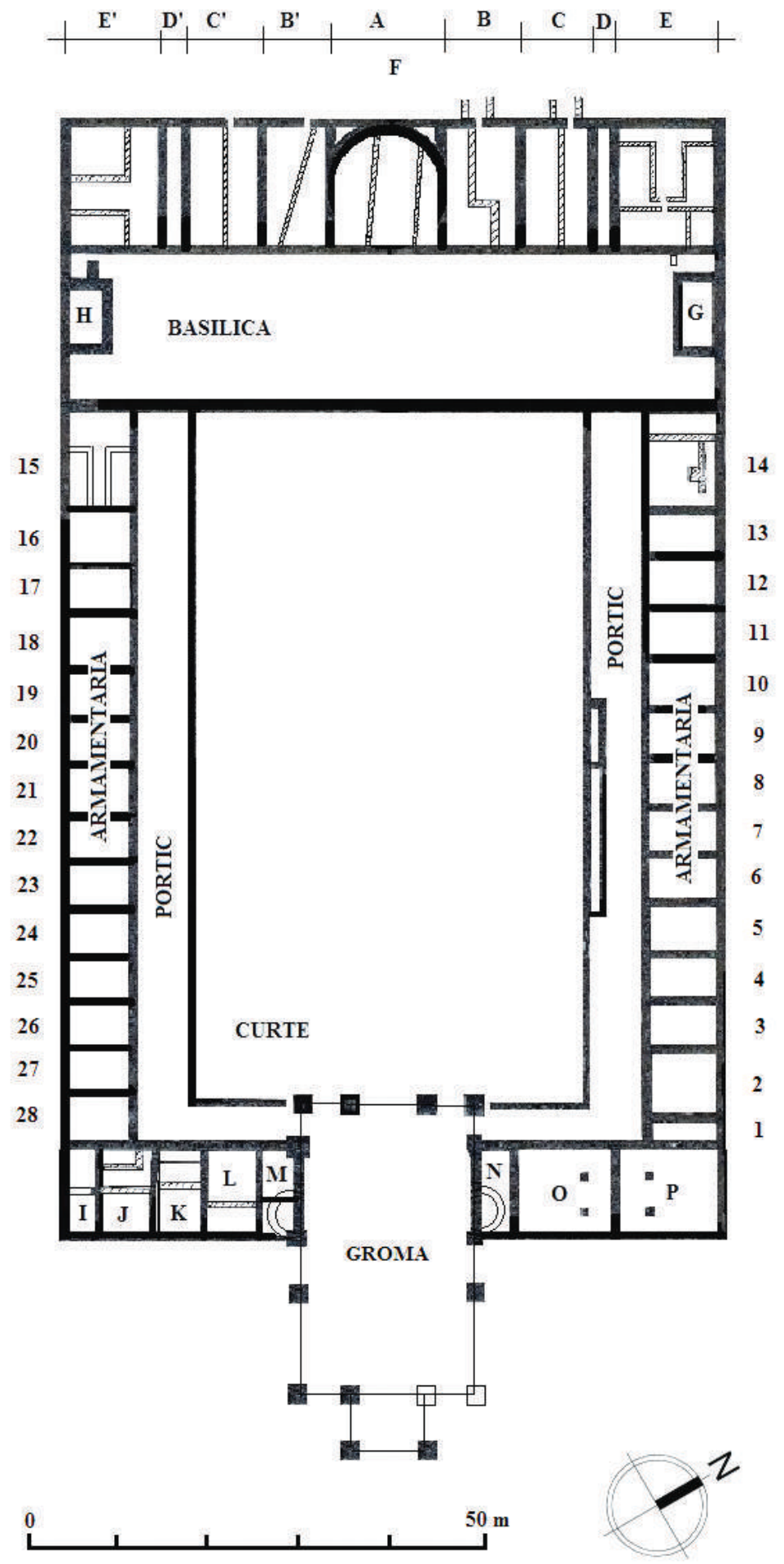

Figura 7. Principia. Plan (2019). 
Distrugerile masive din evul mediu și epoca modernă au făcut ca din statuile de bronz aurit să se descopere fragmente insignifiante. Toate inscripțiile descoperite în basilica sunt păstrate fragmentar. Tituli honorarii din principia privesc în special pe membrii casei domnitoare a Severilor, dar și pe unii din împărații următori, până la familia lui Filip Arabul ${ }^{36}$. Cele mai interesante monumente din basilica sunt inscripțiile închinate împăratului Caracalla și Iuliei Domna, doi laterculi de prin anii 213-214, care menționează 36 centurioni ${ }^{37}$.

Tribunalia G și H. La extremitățile basilicii s-au descoperit fundațiile și puțin din elevația substrucțiilor care susțineau câte un podium (suggestus, tribunal).

Latura de vest închidea edificiul comandamentului. În centru se afla aedes principiorum (A), cu aerarium (F) dedesubt, flancat de încăperi simetrice, anume: două încăperi (B și C, respectiv B'și C'), un coridor (D, respectiv D') și o încăpere (E, respectiv E'). Această succesiune de încăperi și coridoare, simetrice față de sanctuarul central (aedes principiorum) este o regulă la principia legionare, de pildă la Noviomagus și Gemellae ${ }^{38}$, bune analogii pentru Potaissa întâlnindu-se mai cu seamă la Inchtuthill, Vindonissa ${ }^{39}$, Berzovia ${ }^{40}$, Novae ${ }^{41}$ etc. Spațiul central A (aedes principiorum, sacellum) este absidat, înscris într-un pătrat, cu dimensiunile interioare 11,80 x 11,60 m, adică $137 \mathrm{~m}^{2}$. Suprafața sa este obișnuită pentru castrele legionare, practic egală cu suprafața sanctuarului de la Novae $\left(136 \mathrm{~m}^{2}\right)^{42}$. La subsolul sanctuarului se afla spațiul F, camera tezaurului (aerarium), unde se păstrau solda legiunii și depozitele personale ale militarilor ${ }^{43}$. Camera $\mathrm{F}$ nu ocupa întreg subsolul sanctuarului, ci doar zona centrală, ușor descentrată față de aedes, un spațiu de $60 \mathrm{~m}^{2}$. Dacă încăperile încălzite cu hipocaust B, C, B' și C' au fiecare un praefurnium spre vest, în afara edificiului, sistemul de încălzire din încăperile de la extremități, E și E', este diferit, cu praefurnium interior. Rostul încăperilor E și E’ pare a fi similar cu al încăperilor I, J, K și L, poate scholae, cu spații de gătit și luat masa. De altfel încăperea E se află în poziție identică cu spațiul pentru gătit şi mâncat din colțul clădirii de comandament de la Novae ${ }^{44}$.

Cea mai valoroasă piesă de echipament militar descoperită în principia este o mare bucată de lorica squamata, cu peste 3000 de solzi de bronz cusuți pe o pânză de cânepă, iar dintre obiectele de artă se remarcă o statuetă de bronz a lui Iupiter fulminans ${ }^{45}$. Nu mai puţin valoroase sunt sfeșnicele de bronz $z^{46}$ și greutățile confirmate de cântar ${ }^{47}$.

Din inscripțiile descoperite la Potaissa, în principia castrului sau în loc necunoscut, rezultă că sub împăratul Gordian III s-au executat lucrări de reparații, amenajări, poate și realocări de spații în principia ${ }^{48}$.

Termel $^{49}$ au fost cercetate integral și recent publicate monografic ${ }^{50}$. Situat în praetentura dextra, edificiului termal are lungimea maximă de 73 m, iar lățimea maximă de 37 m (Fig. 8-9). Suprafaţa construită a termelor este 1850 m², adică 0,8 \% din suprafața castrului. În general termele militare - fie legionare, fie ale auxiliilor - ocupă 1 - 1,45 \% din suprafața castrului. Termele de la Potaissa sunt destul de mici, spre deosebire de dimensiunile neobișnuit de mari ale clădirii comandamentului.

Intrarea se făcea de pe via praetoria, mai întâi într-un spațiu adiacent, inițial descoperit (o curte), apoi acoperit, care făcea legătura cu palaestra. Urma o basilica thermarum (19,30 x 9,20 m), ulterior mărită $(29,60$ x 10,34 m). Basilica este orientată aproximativ est-vest, fiind dispusă transversal pe blocul central al termelor, orientat nordsud; este posibil ca basilica să fi fost adăugată ulterior blocului central, ca și în cazul altor terme.

În blocul central o axă longitudinală despărțea - într-o primă fază de funcționare - spațiile reci din partea răsăriteană de spațiile calde dinspre apus (Fig. 10-11). Se respecta, prin urmare, principiul vitruvian care prevedea îndreptarea fațadei băilor calde „spre apusul de iarnă”51. Din basilica se intra într-un frigidarium/vestibulum (E) rectangular (23

\footnotetext{
36 Bărbulescu 2012, 95-173.

37 Bărbulescu 2012, 100-153.

38 Trousset 1977,572 .

39 Fellmann 1983, 61, 63.

40 Flutur 2011, 160.

41 Sarnowski 1991, 304.

42 Sarnowski 1977, 412.

43 Vegetius, II, 20.

44 Sarnowski 2018, 356.

45 Bărbulescu 2015, 118-123, fig. 145-150.

46 Bărbulescu 2015, 141-147, fig. 209-223.

47 Bărbulescu 2012, 236-243, fig. 112-124.

48 Bărbulescu 2012, 88-89.

49 Bărbulescu et al. 1999, 431-441.

50 Bărbulescu et al. 2019.

51 Vitruvius, V, 10, 1.
} 


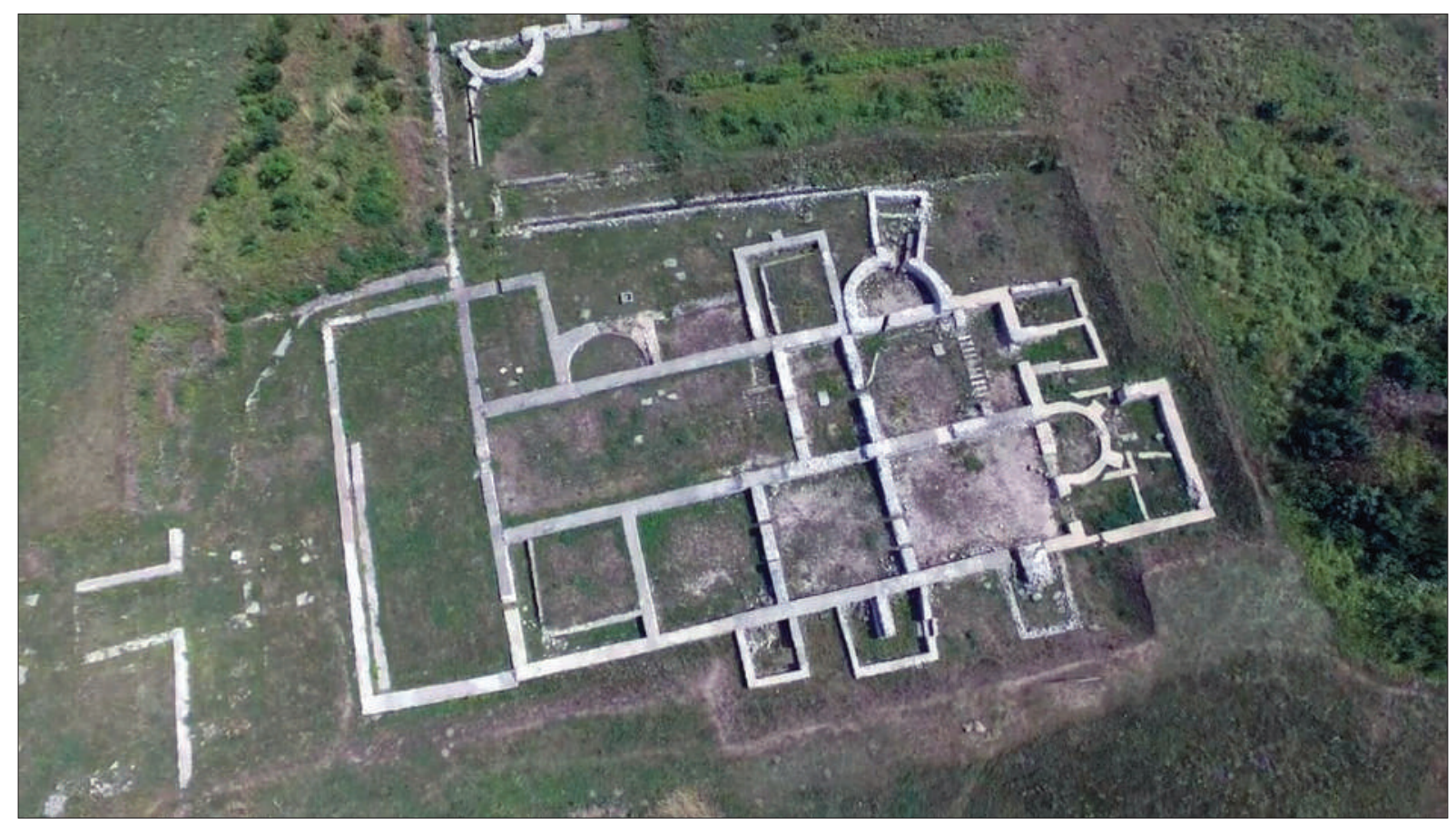

Figura 8. Termele (după Bărbulescu et al. 2019).
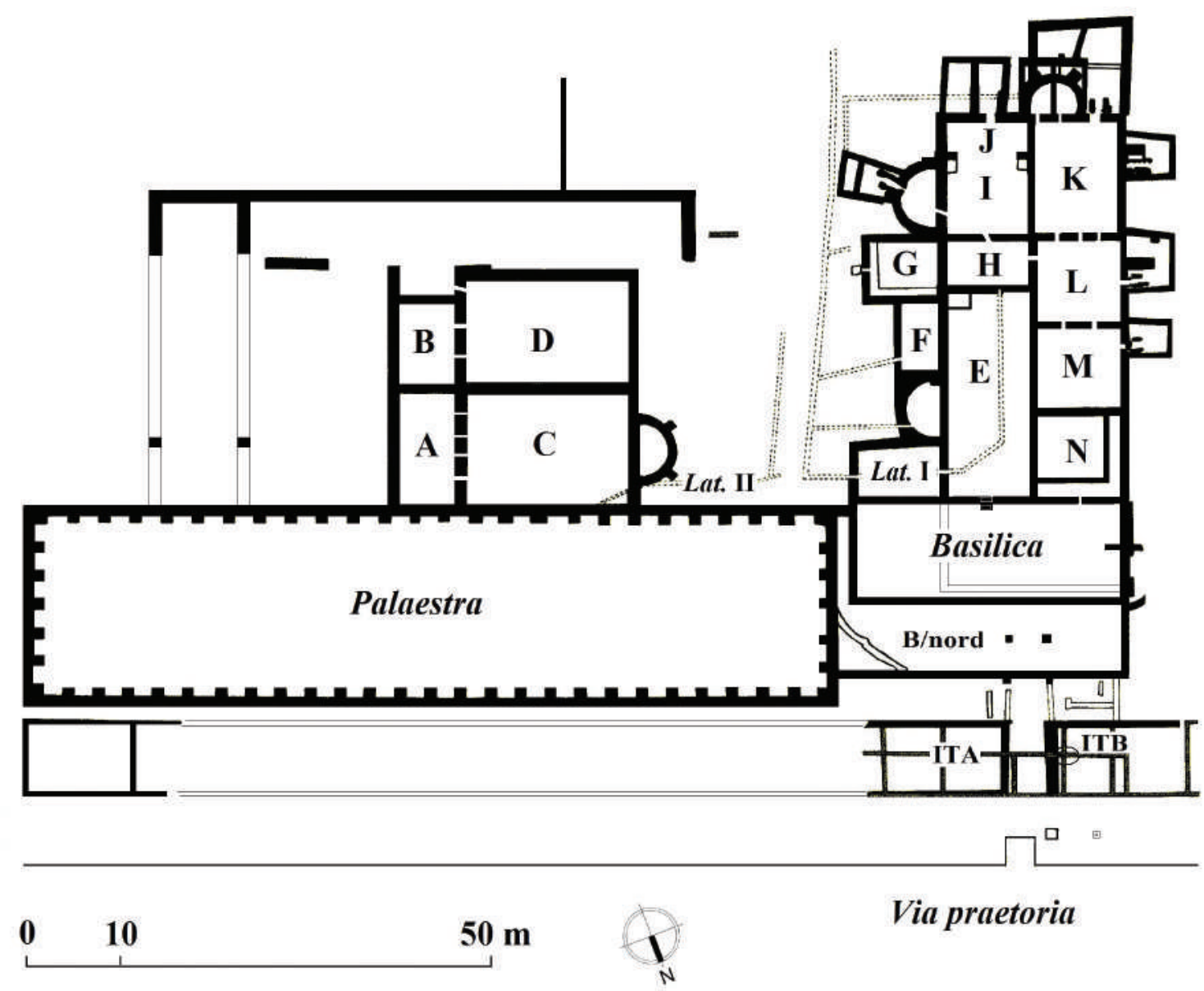

Via praetoria

Figura 9. Termele, palaestra și edificiul ABCD (după Bărbulescu et al. 2019). 
x 9 m). Cele mai interesante descoperiri din spaţiul E sunt două baze de statui cu dedicații pentru Fortuna, respectiv Aesculapius și Hygia, monumente așezate în secolul III, în vremea unui împărat cu nume martelat. Dedicantul ambelor monumente este un praef. alae I Batavorum, agens vice praef. leg. ${ }^{52}$, o funcție necunoscută până în prezent, care reflectă o situație de criză, când rolul cavaleriei sporește și când aceeași persoană deține comanda legiunii de la Potaissa și a alei I Batavorum. Termele și edificiul alăturat ABCD erau decorate și cu alte statui, din care s-au păstrat capul unei statui de calcar a lui Serapis și bustul de marmură a lui Hercules, tipul „Farnese"

Din frigidarium/vestibulum E se intra, la stânga, în latrina I (9 x 5,70 m), cu canalul prin centrul încăperii. Aici s-a descoperit un mormânt de înhumație germanic (probabil gepidic), cu inventar foarte bogat, al unei aristocrate de pe la sfârșitul secolului V - începutul secolului $\mathrm{VI}^{54}$, cea mai interesantă mărturie a epocii migrațiilor la Potaissa, încadrabilă în orizontul Cluj-Someșeni - Apahida. La dreapta se afla încăperea pătrată N (9 x 9 m), care prin poziție şi prin materialul arheologic descoperit era apodyterium. Spre frigidarium/vestibulum E se deschideau două piscinae: un bazin semicircular cu suprafața de $38 \mathrm{~m}^{2}$ și bazinul rectangular F $(7,60 \mathrm{x} 4,10 \mathrm{~m})$. În colțul spațiului $\mathrm{E}$ exista un mic bazin rectangular (cadă ? pediluvium ?). Spre sud de bazinul F exista încăperea rectangulară G (7,5 x 5,95 cm), iniţial încălzită cu hipocaust, apoi transformată în frigidarium.

Apele uzate din latrina I și din toate bazinele reci erau colectate de canalul deversor I, situat în afara termelor, de-a lungul laturii lor estice. După orientare, canalul se îndrepta spre latura sudică a castrului și se scurgea pe panta dealului Cetăţii, spre pârâul Sândului. Zidurile canalului erau construite în opus incertum (înălţime 120 cm), fundul era din cărămidă (lăţime $70 \mathrm{~cm}$ ), iar acoperirea se realiza din lespezi mari, la nivelul solului din antichitate.

În jumătatea vestică a termelor se aflau spațiile încălzite: tepidarium-destrictarium M $(8,90$ x 9 m) și tepidarium (laconicum ?) L (8,95 x 9,10 m). Ambele aveau praefurnia spre vest. În colțul sud-vestic al termelor, cel mai potrivit (cel mai încălzit natural), se află încăperea K, formată dintr-un spațiu rectangular (12,20 x 9,10 m) și o absidă spre sud. Spațiul K era, inițial, caldarium, cu amenajări pentru baia caldă (alveus) în zona rectangulară şi un labrum în absidă (laconicum). Un praefurnium era lipit de absidă, spre sud. Un alt praefurnium exista la vest de spațiul rectangular. Ulterior s-a desființat absida și praefurnium-ul acesteia, deschizându-se un alt praefurnium spre sud de spațiul rectangular. Este imposibil de precizat contemporaneitatea noului praefurnium sudic cu praefurnium-ul vestic și nici dacă ambele funcționau permanent, ori unul era rezervă pentru sezonul rece.

O modificare importantă a suferit circuitul termal când spațiul K a devenit tepidarium, iar caldarium s-a instalat în încăperea I, din colțul sud-estic al blocului termal. Încăperea I (împreună cu așa-numitul spațiu J dinspre sud) a fost, inițial, un frigidarium aliniat cu celelalte frigidaria din partea răsăriteană a termelor. Încăperea era rectangulară (9 x 12,5 m), cu o absidă spre răsărit, în care se găsea bazinul cu apă rece. Spațiul I-J a devenit apoi caldarium. Pentru noua funcțiune s-au amenajat două praefurnia, unul spre sud, celălalt lipit de absidă (poziția celui din urmă şi ductul oblic al cuptorului dovedesc amenajarea lor ulterioară).

La sud de frigidarium-vestibulum E se găsea și spațiul H (9,05 x 4,90 m). Inițial cu destinație necunoscută, spațiul $\mathrm{H}$ a fost amenajat ulterior ca frigidarium, pentru ca, în final, să fie transformat în tepidarium. La ultima funcțiune a ajuns deodată cu introducerea încălzirii în absida de la încăperea I, de unde aerul cald era dirijat și spre camera H. Tepidarium H era acum unicul spațiu încălzit din terme care nu dispunea de praefurnium propriu, având, prin urmare, o temperatură mai scăzută decât celelalte tepidaria. Funcționa ca tepidarium de ieșire.

Palaestra este un edificiu hipetru, poziționat paralel cu via praetoria (Fig. 9), ocupând o suprafață de 2133 m² (prin interior are 91,15 x 23,40 m). Cu această suprafață palaestra de la Potaissa se înscrie printre cele mijlocii ca mărime din castrele legionare sau de la marile terme urbane. Presupunem că pe soclurile lipite de zidul perimetral se înălţau coloane adosate ori angajate. Porticele lipsesc, ca la Aquincum ${ }^{55}$ și Odessos ${ }^{56}$. De altfel, lățimea „liberă” a edificiului (fără socluri) era de numai 19 m (14 m la Odessos); amenajarea unor portice, oricât de puțin adânci, ar fi micșorat prea mult ,spațiul util” al construcției. Nefiind acoperită, palaestra se folosea în funcție de anotimp; pe vreme neprielnică exercițiile fizice se efectuau, poate, în spațiul acoperit lipit de basilica ori chiar în basilica.

Edificiul numit convențional ABCD, incomplet cercetat, se află lipit de palaestra, spre sud (Fig. 9). Din câte se pare, lungimea sa era 53 m (sau 60 m), iar lăţimea era de 35 m. Există dovezi că a fost încălzit (se păstrează canale prin zid pentru trecerea aerului cald), chiar dacă nu s-au descoperit praefurnia ori pile de hipocaust. Cel puțin spațiile centrale erau acoperite cu bolți din „,beton roman”. Sunt două ipoteze privind funcționalitatea

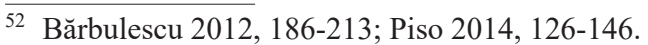

53 Bărbulescu 2015, 40-43, fig. 9-14; 43-44, fig. 16-18.

54 Bărbulescu 2008.

55 Kaba 1991, 13-14.

56 Mirtschev 1967, 7.
} 
sa: a) reprezintă primul edificiu termal, ridicat deodată cu castrul, cu palaestra, așadar terme anterioare celor descrise mai sus; dar nu se poate explica, deocamdată, de ce ar fi fost dezafectate și abandonate „termele ABCD” pentru a se ridica altele, în imediata vecinătate; b) edificiu cu denumire și destinație necunoscută (în nici un caz praetorium), prevăzut cu sistem de încălzire, care a suferit distrugeri mai grave decât orice alt edificiu din castru, după abandonarea acestuia.

Între edificiul ABCD și terme se remarcă latrina II (fig. 9), cu funcționare anterioară latrinei I, dar şi concomitent cu latrina I, și un presupus canal deversor II.

Termele au fost construite deodată cu castrul, în primii ani după 169-170, ori mai târziu, la sfârșitul secolului II sau în secolul III (dacă luăm în considerare ipoteza că edificiul ABCD ar fi fost primele terme din castru). Cea mai apropiată analogie, din punctul de vedere al dispunerii spațiilor, o găsim la termele ceva mai mici, ale castrului auxiliar de la Weißenburg (etapa III, după războaiele marcomanice) ${ }^{57}$ : în ambele cazuri intrarea se face printr-o basilica situată spre nord și dispusă transversal pe celelalte spații; urmează un apodyterium, câte două tepidaria şi un caldarium spre vest; frigidarium ori frigidaria spre est. Înscrierea termelor într-un dreptunghi este mai evidentă la Potaissa. Contemporaneitatea termelor Weißenburg III și Potaissa indică un model „standardizat” în liniile sale generale, pus în operă în castre legionare şi auxiliare. Analogia cu terme din castre auxiliare nu este de natură să susțină, cum cred uniii ${ }^{58}$, că rolul termelor militare ar fi fost diferit: o importantă funcție socială a termelor legionare versus doar rolul primar, pur și simplu de îmbăiere, care le era rezervat auxiliarilor în termele lor.

Privind circuitul termal și includerea termele legionare de la Potaissa în tipologiile existente, faza I-a de utilizare ar aparține tipului numit de A. Bouet „cu itinerar semi-retrograd și semicircular”59 (când utilizatorul nu revine - în „,ircuitul” său - decât în unele din spațiile încălzite deja traversate). Într-adevăr, în această etapă, după ce pătrundea în basilica, militarul intra în apodyterium $\mathrm{N}$ (direct din basilica, ori prin frigidarium/vestibulum E). Urma apoi segmentul liniar tepidarium M (care era, poate, și destricarium) - tepidarium $\mathrm{L}$ - caldarium $\mathrm{K}$. De aici, pentru a nu intra brusc într-un spațiu rece, se întorcea în tepidarium $\mathrm{L}$ și abia apoi pătrundea în zona rece a termelor. Întâlnea spaţiul H, neîncălzit iniţial, apoi frigidarium; de acolo militarii se dispersau în frigidarium I (cu piscina rece în absidă), în frigidarium G și în frigidarium/vestibulum E cu piscinele sale reci. Etapa a II-a de utilizare a termelor se produce odată cu mutarea caldarium-ului din spațiul K în spațiul I. Acum termele potaissense s-ar înscrie în tipul „circular” (tipul Krencker 2, „Ringtyp”) ${ }^{60}$, sau tipul „,continuu, circular şi sinistrogir” din clasificarea lui Y. Thébert $^{61}$. Este un circuit continuu, în care se trece dintr-o sală în alta, fără reveniri pe traseul deja parcurs și fără ca utilizatorii să se încrucișeze cu cei care sosesc. Din apodyterium N se intra în linia dreaptă de tepidaria $\mathrm{M}, \mathrm{L}$ și K. De obicei caldarium-ul asigura schimbarea direcției. Acum schimbarea direcției se face în tepidarium K. De acolo se intra în caldarium I, apoi în tepidarium de ieșire H și, în sfârșit, în toate spațiile reci (G şi frigidarium/ vestibulum $\mathrm{E})$.

Un complex de horrea $^{62}$ a fost descoperit în latus praetorii sinistrum, destul de aproape de porta principalis sinistra, o poziție firească într-un castru (fig. 3). Este format din două horrea, cu un spațiu de circulație (o curte) între ele (sau trei horrea alipite ?). Lățimea totală a complexului este de 36 m, adică 120 pedes. Lungimea nu se poate, deocamdată, preciza. Este posibil ca să se fi extins până la via principalis. Compartimentele laterale au lățimea de 13,5 m, egală cu lățimea pe care o au horrea de la Deva (Chester) ${ }^{63}$. Construcția este tipică pentru aceste depozite, cu contraforți perimetrali, cu podele suspendate pe ziduri dispuse transversal (în compartimentul nordic) sau pe pile din piatră (în compartimentul sudic). S-a observat un interesant sistem de ,îmbrăcare” a zidurilor din piatră cu cărămizi din chirpici, un strat termoizolant împotriva încingerii grânelor.

Cazărmile soldaților (barăcile). Au fost cercetate parțial cazărmile cohortei miliaria din latus praetorii dextrum, fiecare centuria având 12 contubernia. În fața lor, până la via principalis, se aflau, probabil, locuințele tribunilor. $\mathrm{Au}$ fost cercetate parţial și cazărmile unor cohortes quingenariae în praetentura sinistra ${ }^{64}$, în latus praetorii sinistrum ${ }^{65}$, în praetentura dextra și în retentura (fig. 3). Aceste centuriae sunt formate din 10 sau 11 contubernia, un contubernium având o suprafaţă între 33 și $48 \mathrm{~m}^{2}$ și nefiind divizat în papilio și arma (sau, cel puțin, nedivizat

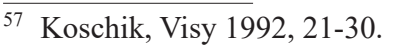

58 Revell 2007, 235-236.

59 Bouet 2003, 176.

${ }^{60}$ Krencker et al. 1929, 177-181.

61 Thébert 2003, 119.

62 Bărbulescu 1987, 164-169.

63 Boon 1973, 138.

${ }^{64}$ Nemeti, Nemeti et al. 2017.

65 Bărbulescu 1987, 169-172.
} 

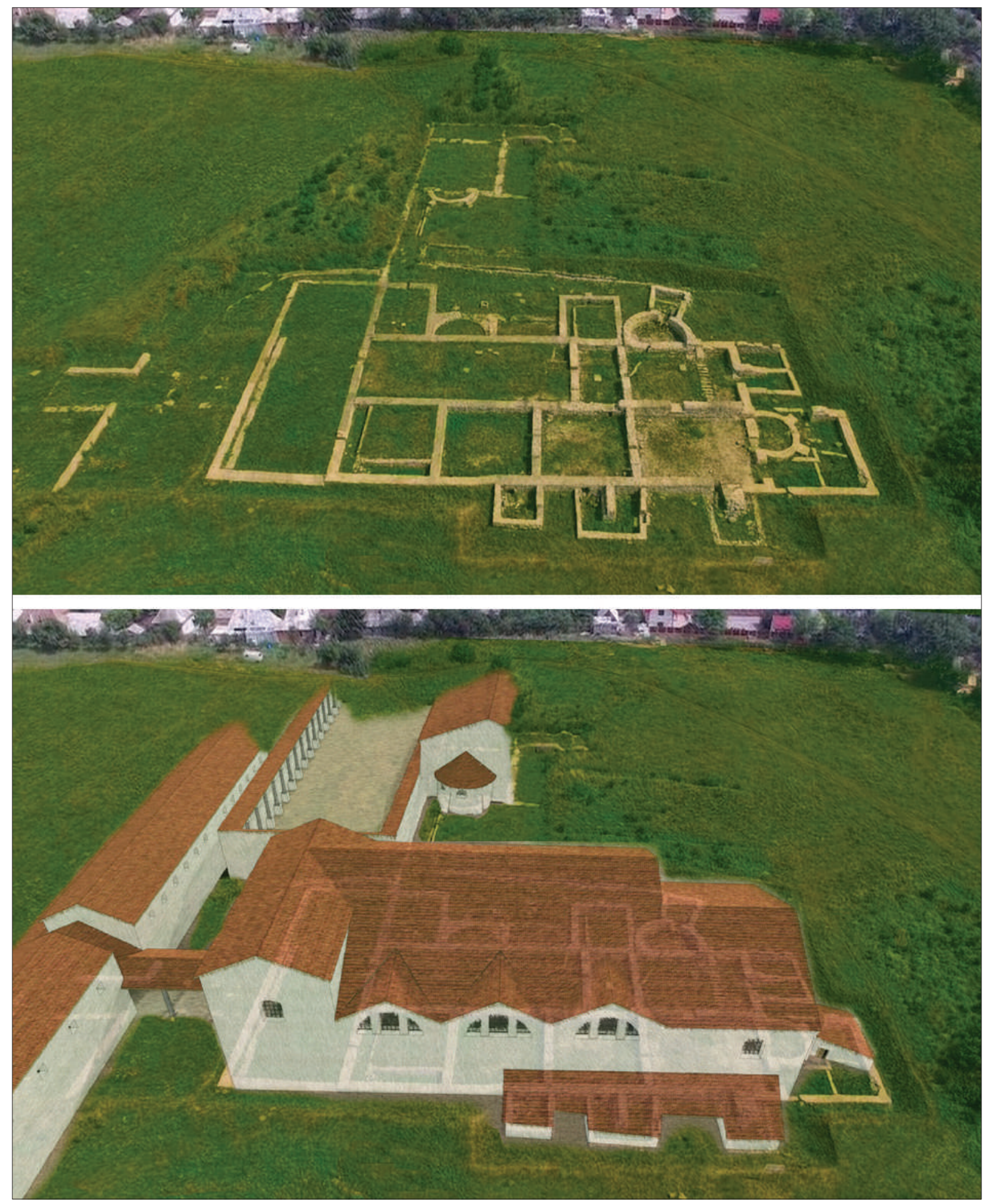

Figura 10. Reconstituirea termelor. Vedere dinspre vest.

Perspectivă suprapusă urmelor arheologice (Cornelia Bărbulescu, Toma Bărbulescu). 

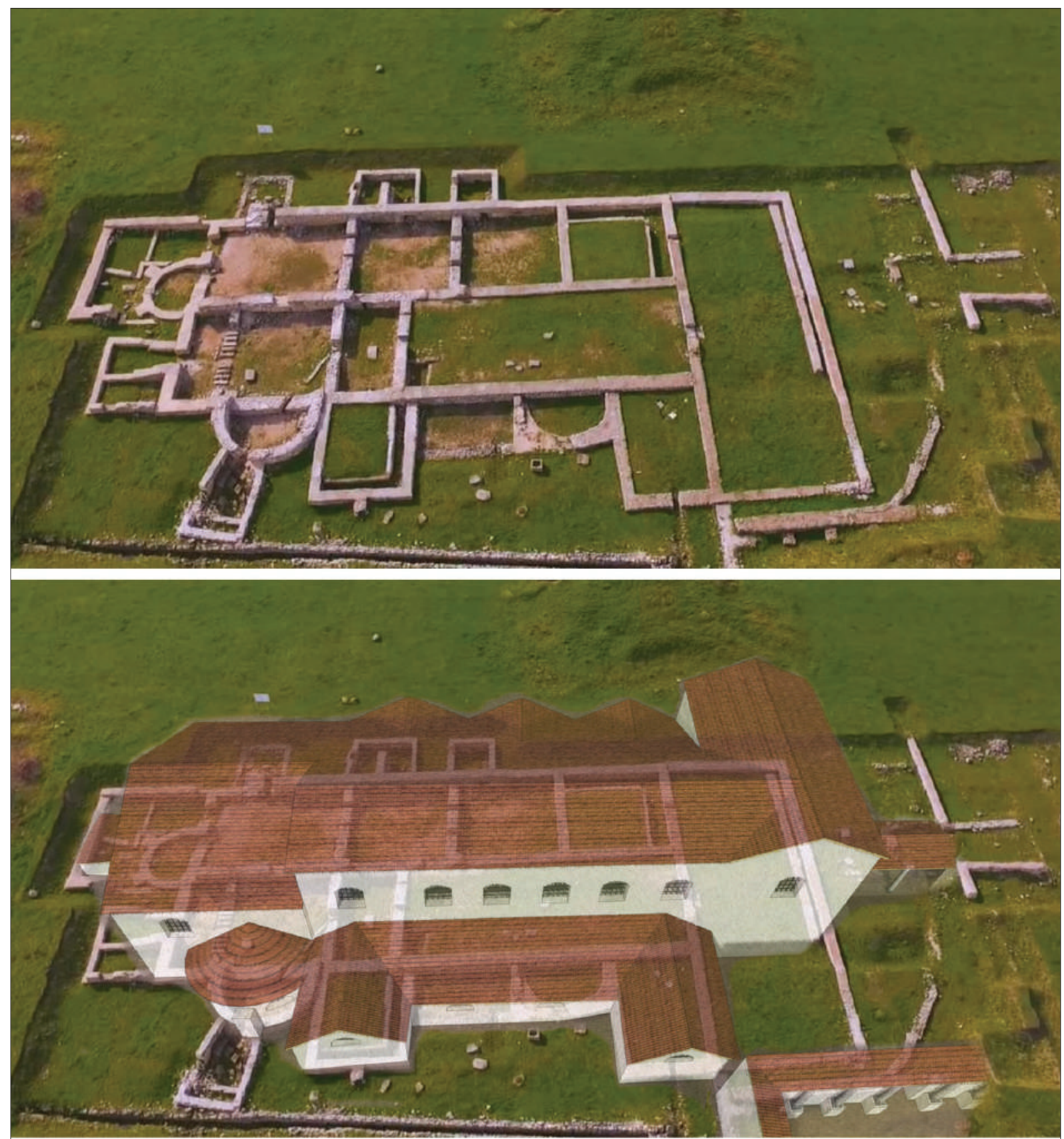

Figura 11. Reconstituirea termelor. Vedere dinspre est. Perspectivă suprapusă urmelor arheologice (Cornelia Bărbulescu, Toma Bărbulescu).

prin amenajări care să lase urme arheologice). Dispunerea față în față a câte două centuriae lasă loc pentru portice puțin adânci (cca $3 \mathrm{~m}$ = decempeda) și curte. Pe lângă bogatul material arheologic (ceramică, ustensile diverse, armament și echipament, monede), cercetările din cazărmi au produs şi descoperiri epigrafice ${ }^{66}$.

După peste patru decenii de cercetări, beneficiind de statutul său de rezervație arheologică, de situaţia de a nu fi fost și de a nu fi suprapus - în proporție de $90 \%$ - de construcții ulterioare epocii romane, precum și de datarea descoperirilor într-un interval relativ ,scurt” (un secol), castrul legionar de la Potaissa a devenit nu doar unul din cele mai de seamă obiective arheologice din epoca romană din România, ci și un reper al arheologiei clasice europene.

${ }_{66}$ Bărbulescu 2012, 174-185, nr. 21; Nemeti, Nemeti et al. 2017, 152. 


\section{BIBLIOGRAFIE}

Bărbulescu 1987

Bărbulescu 1990

Bărbulescu 1991

Bărbulescu 1994

Bărbulescu 1994a

Bărbulescu 1997

Bărbulescu 2004

Bărbulescu 2008

Bărbulescu 2012

Bărbulescu 2015

Bărbulescu 2019

Bărbulescu, Bărbulescu 2004

Bărbulescu et al. 1999

Bărbulescu et al. 2019

Bechert 1971

Bishop 2012

Boon 1973

Bouet 2003

CIL

Crișan 1961

Cupcea et al. 2018
Bărbulescu, M., Din istoria militară a Daciei romane. Legiunea V Macedonica și castrul de la Potaissa, Cluj-Napoca, 1987.

Bărbulescu, M., Les Principia du camp légionnaire de Potaissa, in Vetters, H., Kandler, M. (ed.), Akten des 14. Internationalen Limeskongresses in Bad DeutschAlteburg/Carnuntum, 14-21 September 1986, Wien, 1990, 821-831.

Bărbulescu, M., Das römische Legionslager von Potaissa (Rumänien), Antike Welt. Zeitschrift für Archaeologie und Kulturgeschichte, 22, 1, 1991, 22-30.

Bărbulescu, M., La legio V Macedonica e lo scavo del castrum di Potaissa, Messana. Università degli Studi di Messina. Facoltà di Lettere e Filosofia, 19, 1994, 195-214.

Bărbulescu, M., Potaissa. Studiu monografic, Turda, 1994.

Bărbulescu, M., Das Legionslager von Potaissa (Turda). Castrul legionar de la Potaissa (Turda), Führer zu den archäologischen Denkmälern aus Dacia Porolissensis 7, Zalău, 1997.

Bărbulescu, C., Arhitectura militară şi tehnica de construcție la romani. Castrul de la Potaissa, Cluj-Napoca, 2004.

Bărbulescu, M., Mormântul princiar germanic de la Turda. Das germanische Fürstengrab von Turda, Cluj-Napoca, 2008.

Bărbulescu, M., Inscripțiile din castrul legionar de la Potaissa. The Inscriptions of the Legionary Fortress at Potaissa, București, 2012.

Bărbulescu, M., Arta romană la Potaissa, București - Cluj-Napoca, 2015.

Bărbulescu, M., The legionary fortress from Potaissa (Turda). 45 years of archaeological research, în Farkas, G. I., Neményi, R., Szabó, M., (eds.), Visy 75. Artificem commendat opus. Studia in honorem Zsolt Visy, Kontraszt Plusz Kf., Pécs, 2019, p. 52-69.

Bărbulescu, C., Bărbulescu, M., Poarta principală a basilicii castrului de la Potaissa, în Crînguș, M., Regep-Vlascici, S., Ștefănescu, A. (ed.), Studia Historica et Archaeologica in honorem Magistrae Doina Benea, Timișoara, 2004, 27-33.

Bărbulescu, M., Cătinaș, A., Luca, C., Husar, A., Huszarik, P., Grec, M., Bărbulescu, C., The Baths of the Legionary Fortress at Potaissa, în Gudea, N. (ed), Roman Frontier Studies. Proceedings of the XVII In International Congress of Roman Frontier Studies, Zalău, 1999, 431-441.

Bărbulescu, M. (coord.), Andone-Rotaru, M., Bărbulescu, C., Bărbulescu, M., Bărbulescu, T., Cătinaş, A., Fábián, I., Fodorean, F.-Gh., Huszarik, P., Munteanu, M., Nedelea, L., Nemeti, I., Nemeti, S., Termele din castrul legionar de la Potaissa, Editura Mega: Cluj-Napoca, 2019.

Bechert, T., Römische Lagertore und ihre Bauinschriften. Ein Beitrag zur Entwicklung und Datierung kaiserzeitlicher Lagergrundrisse von Claudius bis Severus Alexander, Bonner Jahrbücher, 171, 1971, 249.

Bishop, M.C., Handbook to Roman Legionary Fortresses, Barnsley, 2012.

Boon, G.C., Caerleon: une forteresse de légion et ses etablissements, Apulum, 11, 1973, 134.

Bouet, A., Les thermes privés et publics en Gaule Narbonnaise, I-II, Roma, 2003. Corpus Inscriptionum Latinarum, Berlin.

Crișan, I.H., Șantierul arheologic Turda. Materiale și cercetări arheologice, 7, 1961, 431-439.

Cupcea, G., Marcu, F., Petiş, I., Bajusz, M., Deac, D., Cociș, H., Zimmermann, M., Castrul auxiliar de la Brusturi/Romita, jud. Sălaj - Reluarea cercetărilor arheologice, LIMES, 4, 2018, 19. 
Fellmann 1958

Fellmann 1983

Flutur 2011

Franzen et al. 2004-2005

Gawlikowski 1984

Groh 2018

Johnson 1987

Kaba 1991

Kandler 1977

Kandler 1979

Kandler, Vetters 1986

Koschik, Visy 1992

Krencker et al. 1929

Lain, Parker 2006

Mirtschev 1967

Nemeti, Nemeti et al. 2017

Ohr 1975

Petrikovits 1975

Piso 2014

Ployer 2013

Póczy et al. 1986

Rakob, Storz 1974

Revell 2007

Sarnowski 1977
Fellmann, R., Die Principia des Legionslagers Vindonissa und das Zentralgebäude der römischen Lager und Kastelle, Brugg, 1958.

Fellmann, R., Principia - Stabsgebäude, Stuttgart, 1983.

Flutur, Al., Clădirile comandamentului din castrul de legiune traianic de la Berzobis, Analele Banatului. Arheologie-Istorie, 19, 2011, 160.

Franzen, P., Matei, Al. V., Marcu, F., The Roman fort at Romita (Dacia). Results of the geophysical survey, Acta Musei Napocensis, 41-42/I, 2004-2005, 165.

Gawlikowski, M., Palmyre. VIII. Les principia de Dioclétien, „Temple des Enseignes", Varsovie, 1984.

Groh, S., Im Spannungsfeld von Macht und Strategie. Die legio II Italica und ihre castra von Ločica (Slowenien), Lauriacum/Enns und Albing (Österreich), Linz (Forschungen in Lauriacum, 16), 2018.

Johnson, Anne, Römische Kastelle, Mainz, 1987.

Kaba, M., Thermae Maiores legionum II Adiutricis, Budapest, 1991.

Kandler, M., Legionslager und canabae von Carnuntum, in Temporini, H., Haase, W. (ed.), Aufstieg und Niedergang der Römischen Welt, II.6, Berlin - New York, 1977, 633.

Kandler, M., Zu den Grabungen F. Lorgers im Legionslager Ločica (=Lotschitz), Arheološki Vestnik, 30, 1979, 190.

Kandler, M., Vetters, H., Der römische Limes in Österreich, Wien, 1986.

Koschik, H., Visy, Zs., Die Großen Thermen von Weißenburg i. Bay, Mainz, 1992.

Krencker, D., Krüger, E., Lehmann, H., Wachtler, H., Die Trierer Kaiserthermen. I. Ausgrabungsbericht und Grundsätzliche Untersuchungen römischer Thermen, Augsburg, 1929.

Lain, A., Parker, S.T., The Principia of el-Lejjūn (Area A), în Parker, S.T. (ed.), The Roman frontier in central Jordan: final report on the Limes Arabicus Project, 1980-1989, I, Washington, 2006.

Mirtschev, M., Die römischen Thermen in Varna. Les thermes romains à Varna, Sofia, 1967.

Nemeti, S., Nemeti, I. (eds.), Andone-Rotaru, Mariana, Bindea, Diana, Blaga, D., Fábián, I., Fodorean, F.-Gh., Munteanu, M., Nedelea, Luciana, Nemeti, Irina, Nemeti, S., Studii asupra granițelor romane din Dacia. Castrul legionar de la Potaissa. I. Centuriae din praetentura sinistra, Editura Mega: Cluj-Napoca, 2017. Ohr, K., Die Form der Basilica bei Vitruv, Bonner Jahrbücher des Rheinischen Landesmuseums, 175, 1975, 115-117.

Petrikovits, H.V., Die Innenbauten römischer Legionslager während der Prinzipatszeit, Düsseldorf-Opladen, 1975.

Piso, I., Zur Reform des Gallienus anläßlich zweier neur Inschriften aus den Lagerthermen von Potaissa, Tyche, 29, 2014, 126-146.

Ployer, R., Der norische Limes in Österreich, Wien, 2013, 34-37.

Póczy, K., Németh, M., Szirmai, K., Kocsis, L., Das Legionslager von Aquincum, in Unz, C. (ed.), Studien zu den Militärgrenzen Roms. III. 13. Internationalen Limeskongress Aalen 1983, Stuttgart, 1986, 398.

Rakob, Fr., Storz, S., Die Principia des römischen Legionslagers in Lambaesis, Mitteilungen des Deutschen Archäologischen Instituts, Römische Abteilung, 81, 2, 1974, 266.

Revell, L., Military Bath-houses in Britain - a Comment, Britannia, 38, 235-236.

Sarnowski, T., Fortress of the Legio I Italica at Novae, în Fitz, J. (ed.), Limes. Akten des XI. Internationalen Limeskongresses Székesfehérvár, Aug-Sept 1976, Budapest, 1977, 412. 
Sarnowski 1991

Sarnowski 1995

Sarnowski 2002

Sarnowski 2018

Speidel, DimitrovaMilčeva 1978

Számadó, Borhy 2003

Szirmai 1976

Thébert 2003

Trousset 1977

Vegetius

Vetters 1977

Vitruvius

Winkler 1971
Sarnowski, T., The Headquarters Building of the Legionary Fortress at Novae (Lower Moesia), în Maxfield, V.A., Dobson, M.J. ed., Roman Frontier Studies 1989. Proceedings of the XV International Congress of Roman Frontier Studies, Exeter, 1991, 304.

Sarnowski, T., Another legionary groma gate hall? The case of Novae in Lower Moesia, Novae. Studies and Materials, 1, 1995, 37-40.

Sarnowski, T., Intra fines Imperii. Centrum obozu w Novae: wykopaliska 19972002, Światowit. Rocznik Instytutu Archeologii Uniwersytetu Warszawskiego, 4 (45), 2, 2002, 164-165.

Sarnowski, T., In medio castrorum legionis I Italicae at Novae Preserved Remains, 3D Virtual Modelling and Full-size Visualization on the Original Site, in Sommer, C.S., Matešic, S. (ed.), Proceedings of the $23^{\text {rd }}$ International Congress of Roman Frontier Studies Ingolstadt 2015, Mainz, 2018, 356.

Speidel, M.P., Dimitrova-Milčeva, A., The Cult of the Genii in the Roman Army and a New Military Deity, în Temporini, H., Haase, W. ed., Aufstieg und Niedergang der Römischen Welt, II/16.2, Berlin - New York, 1978, 1551-1552.

Számadó, E., Borhy, L., Brigetio Castra Legonis, in Visy, Zs. (ed.), The Roman Army in Pannonia, Budapest, 2003, 77.

Szirmai, K., Előzetes beszámoló az óbudai legiostábor principiáján és közvetlen környékén végzett kutatásokról, Budapest régiségei, 24, 1, 1976, 91-93.

Thébert, Y., Thermes romains d'Afrique du Nord et leur contexte méditerranéen, Rome, 2003.

Trousset, P., Le camp de Gemellae sur le limes de Numidie d'après les fouilles du colonel Baradez (1947-1950), in Fitz, J. (ed.), Limes. Akten des XI. Internationalen Limeskongresses Székesfehérvár, Aug-Sept 1976, Budapest, 1977, 572.

Epitoma rei militaris. Epitome of Military Science, trad. Milner, N. P., Liverpool, 2011.

Vetters, H., Lauriacum, in Temporini, H., Haase, W. (ed.), Aufstieg und Niedergang der Römischen Welt, II.6, Berlin - New York, 1977, 363.

Vitruvii Pollionis de architectura libri X. Vitruviu, Despre arhitectură, trad. Cantacuzino, G.M., Costa, T., Ionescu, Gr., București, 1964.

Winkler, G., Legio II Italica. Geschichte und Denkmäler, Jahrbuch des Oberösterreichischen Musealvereines, 116, 1971, 85-107. 


\section{LIST OF ILLUSTRATIONS}

Figure 1. The legionary fortress from Potaissa. Overview (after Bărbulescu et al. 2019).

Figure 2. The legionary fortress from Potaissa. Photography (Toma Bărbulescu) and plan.

Figure 3. The legionary fortress from. Plan (2019).

Figure 4. Principia and thermae (after Bărbulescu et al. 2019).

Figure 5. Principia and thermae (after Bărbulescu et al. 2019).

Figure 6. Principia. Photography and plan.

Figure 7. Principia. Plan (2019).

Figure 8. Thermae (after Bărbulescu et al. 2019).

Figure 9. The thermae, the gymnasium and Building ABCD (after Bărbulescu et al. 2019).

Figure 10. Reconstruction of thermae. View from the west. Perspective superimposed on the archaeological context (Cornelia Bărbulescu, Toma Bărbulescu).

Figure 11. Reconstruction of thermae. View from the east. Perspective superimposed on the archaeological context (Cornelia Bărbulescu, Toma Bărbulescu).

Prof.dr. MIHAI BĂRBULESCU, membru corespondent al Academiei Române, Universitatea „Babeș-Bolyai” Cluj-Napoca, mihaibarbulescu47@gmail.com 